market uses of the CFCs of concern. One of these alternatives, CFC-22, is already produced in large quantities, and could be employed more broadly in refrigeration and airconditioning in place of CFC-12 if appropriate use-equipment were developed.

Neither the market-place nor regulatory policy, however, has provided the needed incentives to make these equipment changes or to support commercialization of the other potential substitutes. If the necessary incentives were provided, we believe alternatives could be introduced in volume in a time-frame of roughly five years. This lengthy lead-time would be needed to complete required toxicity testing, to design and build production facilities, and to make the necessary changes in applications equipment. We have recently reviewed and updated our earlier work, and will share our assessment of the technically viable substi- tutes with EPA and our customers in the coming months.

Finally, we believe it is important for the CFC producerand user-industries to develop improved conservation and recovery practices to reduce atmospheric emissions of CFCs. DuPont is studying a variety of technical and administrative approaches to reduce emissions, and we will share our views with the appropriate audiences in the coming months.

\section{JosePh P. GLas, Director}

Freon Products Division

Chemicals \& Pigments Department

E.I. DuPont de Nemours \& Company Wilmington

Delaware 19898, USA.

\title{
Links Between Ozone Depletion and the Greenhouse Effect
}

The same gases which deplete ozone in the stratosphere contribute to the 'greenhouse effect' while they reside in the troposphere, or lower atmosphere. Chlorofluorocarbons (CFCs), which deplete ozone, are currently estimated to contribute about $15 \%$ of the annual increase of total global warming. Other so-called 'greenhouse gases' contribute the remainder.

Ozone exists throughout the stratosphere and the troposphere, where it acts as a 'greenhouse gas'. Ozone can increase in the troposphere as a result of ozone depletion in the stratosphere and as a result of the emissions of Manmade pollutants. Ozone in the troposphere currently is a significant 'greenhouse gas' contributing $7-8 \%$ of annual 'greenhouse warming'.

As ozone controls the temperature structure of the stratosphere, ozone depletion could have an impact on cli- mate-adding to the changes brought about by the warming of the lower atmosphere by 'greenhouse gases'.

A general warming of the Earth's climate could increase demands for air-conditioning, thereby increasing demands for CFCs, emissions of which would further deplete stratospheric ozone and amplify warming. Increased air-conditioning could also lead to an increase in the emissions of carbon dioxide as a result of increased demand for electricity generated by fossil fuels, further amplifying global warming.

WORLD RESOURCES INSTITUTE
1735 New York Avenue, $N W$
Washington
DC 20006
USA.

WORLD RESOURCES INSTITUTE Washington

USA.

\section{Waste Minimization Forums Delineate 'State of the Art' of Efforts to Eliminate Hazardous Effluents at the Source}

A series of professional forums in the United States has documented the vast potential, as well as significant obstacles, that are in store for waste minimization-systems approaches to reduction or elimination of hazardous effluents in industrial processes prior to the treatment stage.

Formally introduced in 1976 as non-waste technology by the Economic Commission for Europe, the concept of waste minimization has recently become of great interest in the United States. As industries seek to reduce hazardouswaste disposal costs and avoid massive liability suits arising from improper disposal, they are turning increasingly towards waste minimization. Consequently late in 1985 the undersigned, Director of the Resource Policy Institute in Washington, DC, teamed up with the Washington-based Government Institutes, Inc., to put together what became the first major professional-level forum series on this topic.

According to information presented in the series, the total hazardous-waste 'stream' could be reduced by as much as $50 \%$ through vigorous waste-minimization programmes. Roughly half of this reduction could be achieved through relatively simple maintenance and redesign efforts, while the other half would have to be accomplished through basic-and potentially costly-redesign of industrial processes.

Lack of basic information, as well as reluctance in the industrial sector to share proprietary information, has hampered waste minimization, according to forum parti- cipants. At the same time procurement policies of industries and government agencies, contractual restrictions, and direct government regulations, can all prove to be significant inhibiting factors for changing standard processes to less-polluting ones.

As discussed in detail at these meetings, government action may be necessary to increase waste minimization activities in the private sector. While the economic incentives for waste minimization are strong, some streamlining of waste minimization mechanisms might be effected through government action. Technical assistance and information transfer-being effected to limited extents in state government agencies-are the most frequently cited forms of federal government involvement. Required reduction targets for the national waste 'stream', grants programmes, and even regulatory concessions which would allow industries to take extra time to develop waste minimization practices in lieu of end-of-pipe treatment systems, should also be mentioned.

While there is disagreement about the role of the federal government in waste minimization, there is considerable agreement about the role of corporate management in the field: the higher the level of management involvement is, the more effective will waste minimization programmes prove to be.

Arthur H. Purcell, Director Resource Policy Institute

P.O. Box 39185

Washington

DC 20016, USA. 